\title{
Productivity of Forages in Grassland Merapi Post-Eruption Area, Sleman, Yogyakarta, Indonesia
}

\author{
Nafiatul Umami ${ }^{1}$, Bambang Suhartanto ${ }^{1}$, Bambang Suwignyo ${ }^{1}$, Nilo Suseno ${ }^{1}$, Sarah Adrian Fenila ${ }^{1}$ \\ Ruslina Fajarwati ${ }^{1}$ \\ ${ }^{1}$ Faculty of Animal Science, University of Gadjah Mada, Jl. Fauna No 3 Yogyakarta 55281 Indonesia \\ Corresponding author email: nafiatul.umami@ugm.ac.id
}

\begin{abstract}
This research was aimed to investigate the productivity and quality of forages (including dry matter, organic matter, crude fiber, crude protein, and extract ether) in the area of Kali Kuning and Krasak River. This area was affected by Mount Merapi Eruption on 2010. The data were taken from the area around the river that was firstly revegetated after the eruption. The forage classified as grass, legume and forbs. The method applied in the research was Line Intercept method by observing the botanical composition there at several observation points. The forage was taken as the sample, then calculated the production, and proximately analyzed to determine its chemical composition. The results showed that around the river, the widest cover area in 2013 and 2014 was Brachiaria brizantha grasses. The highest dry matter in 2013 and 2014 was 165.57 $\mathrm{gm}^{-2}$ in Pennisetum purpuphoides and $190.37 \mathrm{gm}^{-2}$ in Brachiaria brizantha, respectively. Forbs with another type of weed also spread in this area. The quality of forages around Krasak River increased in 2014 due to the addition of organic matter contained in the soil and the minerals weathering from year to year.
\end{abstract}

Key words: grassland area, Merapi Indonesia, legum, grass, production

Abstrak. Penelitian ini bertujuan untuk mengetahui produktivitas dan hijauan (termasuk bahan kering, bahan organik, serat kasar, protein kasar dan ekstrak eter) di daerah Kali Kuning dan Kali Krasak. Wilayah tersebut merupakan area terdampak letusan Gunung Merapi pada tahun 2010. Data diambil dari area di sekitar sungai dengan pertimbangan area tersebut yang pertama kali mengalami revegetasi setelah terjadinya erupsi. Hijauan dikategorikan dalam rumput, legum dan rambanan. Metode yang digunakan dalam penelitian ini adalah metode Line Intercept dengan mengamati komposisi botani yang ada di lokasi. Pengamatan dilakukan di beberapa titik observasi. Hijauan sampel diambil dan dihitung produksi serta komposisi kimianya menggunakan analisis proksimat. Hasil penelitian menunjukkan bahwa hijauan yang mendominasi di sekitar sungai pada tahun 2013 dan 2014 dalah rumput Brachiaria brizantha. Produksi bahan kering tertinggi pada tahun 2013 adalah Pennisetum purpuphoides sebanyak $165.57 \mathrm{gm}^{-2}$, sedangkan pada tahun 2014 produksi BK tertinggi adalah Brachiaria brizantha sebanyak $190.37 \mathrm{gm}^{-2}$. Rambanan dan beberapa jenis rumput lapang juga tumbuh di area tersebut. Kualitas hijauan di sekitar sungai Krasak meningkat pada tahun 2014 sebagai akibat adanya tambahan material organic di dalam tanah dan mineral dari tahun ke tahun.

Kata kunci: padang rumput, Merapi Indonesia, legume, rumput, produksi

\section{Introduction}

Mount Merapi in Indonesia is an active volcano, with an altitude of 2980 meters above sea level. This mount is one of the most active volcanoes in the world. Almost every period Mount Merapi erupts. The period of eruption activity occurs ranging between 2-7 years (Susilo and Iwan, 2014). The last eruption of Mount Merapi on 26 October to 5 November 2010 caused various environmental damage to the land, water, crops, livestock deaths, human fatalities, pollution and disruption of social and economic activities in the affected areas. Many agricultural land ( $\pm 281 \mathrm{ha}$ ) were damaged by volcanic ash released at the time of the eruption of Mount Merapi. The amount of volcanic ash was estimated reaching more than 140 million $\mathrm{m}^{3}$ (IAARD team, 2010). As a result, farmers lost their source of forages for feeding livestock since almost the entire feed crops was dead by the heat of volcanic ash $\left(600^{\circ} \mathrm{C}\right)$. 
The soil type around the volcano is volcanic soil which is generally very fertile. Volcanic soils formed as a result of volcanic eruption, the earth layer is formed from volcanic eruptions materials that have weathered. Kusnadi (2008) states that volcanic soil is fertile and contains high nutrients. Volcanic soil is formed with the addition of volcanic ash from an erupting volcano. Volcanic ash gives long-term benefits to increase soil fertility despite of its short-term negative effect due to the mineral content of the ash may not be available to be absorbed by the plants so that it should be supported with fertilization to maintain soil fertility (Rostaman, 2011).

Forage is the feed material that is absolutely necessary both quantitatively and qualitatively throughout the year in ruminant livestock production systems. It consists of grasses and legumes. The portion of forage in ruminant rations reaches 40 to $80 \%$ of the total ration dry matter or about 1.5 to $3 \%$ of the live weight of cattle. Nutritionally, forage is a source of fiber, even legume forage can be cheap mineral and protein supplement for ruminants (Abdullah, 2012). Grazing land is an area where forages grow and will be available for livestock to meet their needs in a short time (Cullison, 1975 cited by Reksohadiprojo, 1994) as of the grazing land used by farmers in the area of Mount Merapi. They gather the forage which grows around Merapi's lava flow stream to be given to the livestock. This forage is given to the cattle with a cut-and-carry system or by directly grazing on the pasture land.

As time goes by, the forage begins to re-grow and green the Mount Merapi land. Kali Kuning and Krasak River are among the areas destroyed by the lava flow of Mount Merapi. The area around the river becomes the major concern because the area was found to be first revegetated after the eruption. Therefore, to determine the production and botanical composition of forage around Kali Kuning and Krasak River, the research on the productivity and quality of forage around Kali Kuning and Krasak River was necessarily to be conducted. One of methods applied to calculate the cover area of crops is the line intercept method. Line intercept is a method which is designed to sampling variation in the plot and calculates the cover change and the height of plant species during the growth time by using transect which is placed in a macroplot. This method is mainly used to monitor the cover change and height of plant species. Line intercept method is suitable for use in open vegetation areas (Caratti, 2006). Cummings and Denny (2000) states that the line intercept method underlined as a tool to quickly decide community structure and investigate the relationship between the plant species and several independent variables that appear throughout the transitional zone. The purpose of this study was to determine the production and quality of forage available around the slopes of Mount Merapi after the eruption of this Mount.

\section{Materials and Method}

The research was conducted in the area of Kali Kuning and Krasak River, Sleman Yogyakarta, Indonesia during September 2013 and November 2014. The data were collected randomly with the distance from one location to the next location in Kali Kuning and Krasak River approximately 100 to 150 meters. The method used was by using the line intercept method which was taken at several observation points. The process is by stretching 30-meters long rope which was then divided into several intervals with the length of each interval was 2 meters. Then note the botanical composition under the rope and measure the length of leaves covering the ground and the plant height.

Sampling was carried out during the dry season. Forage around Kali Kuning and Krasak River was taken as a sample approximately 500 grams. Forage sample which was grown on an 
estimated area of $1 \mathrm{~m}^{2}$ then was taken and weighed, and then calculated its dry matter production. This sample was then weighed and put into oven and later on was analyzed chemically by proximate analysis. The samples analysis was carried out by proximate analysis including dry matter (DM), organic matter $(O M)$, ash, crude fiber (CF), extract ether (EE), and crude protein (CP) (AOAC, 2005). After obtaining the results of dry matter, ash, crude fiber, crude fat and crude protein then the extracted material without its nitrogen was calculated by using the formula:

$$
\begin{aligned}
\operatorname{BETN}(\%)= & 100 \%-(\% \text { of water }+\% \text { of ash }+\% \text { of } \\
& \text { CP }+\% \text { of } C F+\% \text { of EE })
\end{aligned}
$$

A total digestible nutrient (TDN) was calculated by using the formula according Hartadiet al. (2005) as follows.

$$
\begin{aligned}
\% T D N= & -54,572+6,769(\mathrm{CF})-51.083(\mathrm{EE})+1,851 \\
& (\mathrm{NFE})-0,334(\mathrm{Pr})-0,049(\mathrm{CF})^{2}+3,384(\mathrm{EE})^{2}- \\
& 0,086(\mathrm{CF})(\mathrm{NFE})+0,687(\mathrm{EE})(\mathrm{NFE})+0,942(\mathrm{E} \\
& \mathrm{E})(\mathrm{Pr})-0,112(\mathrm{EE})^{2}(\mathrm{Pr})
\end{aligned}
$$

The data of production measurement during the dry season months in September 2013 and September 2014 will be analyzed using t-test.

\section{Results and Discussion}

\section{Productivity of grazing land in Kali Kuning and Krasak river}

The grazing land measured its productivity and cover area was around the Kali Kuning and Krasak River in Tunggularum, Wonokerto, Turi, Sleman, Yogyakarta. In this region, there are many grazing lands used by local people to collect the grasses. This study was conducted during September 2013 to September 2014. Based on the data obtained from Indonesian Agency for Meteorology, Climatology, and Geophysics, the temperature, rainfall and humidity in September 2013 to September 2014 can be seen in Table 1.

Based on Table 1 it can be seen that the temperature, rainfall, and humidity were $26.8^{\circ} \mathrm{C}, 0.9 \mathrm{~mm}$, and $72 \%$, respectively. The temperature, rainfall and humidity in September 2014 were $26.4^{\circ} \mathrm{C}, 0 \mathrm{~mm}$, and $79 \%$, respectively.

Table 1. Data of temperature, rainfall, and humidity in September 2013 to September 2014

\begin{tabular}{lccc}
\hline \multicolumn{1}{c}{ Month } & Temperature $\left({ }^{\circ} \mathrm{C}\right)$ & Rainfall $(\mathrm{mm})$ & Humidity (\%) \\
\hline September 2013 & 26.8 & 0.9 & 72 \\
October 2013 & 28.0 & 43.3 & 73 \\
November 2013 & 27.0 & 407.8 & 81 \\
December 2013 & 26.3 & 329.5 & 85 \\
January 2014 & 26.2 & 414.5 & 86 \\
February 2014 & 26.5 & 336.9 & 85 \\
March 2014 & 27.4 & 135.3 & 81 \\
April 2014 & 27.2 & 283.3 & 83 \\
May 2014 & 27.7 & 18.7 & 78 \\
June 2014 & 27.6 & 46.4 & 78 \\
July 2014 & 26.3 & 36.7 & 79 \\
August 2014 & 26.4 & 1.5 & 79 \\
September 2014 & 26.4 & - & 79 \\
\hline \multicolumn{1}{c}{ Total } & 349.8 & 2045.8 & 1039 \\
\hline
\end{tabular}

(Indonesian Agency for Meteorology, Climatology, and Geophysics, 2014) 
Prawiradiputra (2003), states that the forage production is influenced by rainfall, so that the fluctuations in forage production during the dry season and the rainy season may be very different.

From Tables 2 and 3, it appears that in the volcanic ash from Mount Merapi eruption, which in 2011 covered the land around the Mount Merapi as thick as $30-50 \mathrm{~cm}$, containing $\mathrm{C}$ and $\mathrm{N}$ in a very small percentage. As the time goes by and the rain falls to the ground, the soil condition changed. In 2013, it appeared that the organic matter of the soil has increased and soil composition was different. The weathering of organic matter increased the soil maturity in area around Mount Merapi, so that the content of $\mathrm{C}$ and $\mathrm{N}$ increase. The increase of $\mathrm{N}$ content in the soil shows that weathering of organic material which release $\mathrm{N}$ for the soil nutrients has occurred. The process of data collection is carried out by measuring the width of crops cover area and the height of the plant. The percentage of cover area and the height of feed crops in the area Krasak River can be seen in Table 4.

Cover area is the width of a land surface which is covered by plants. Table 4 above shows that the number and the type of botanical composition during the observation in September 2013 and September 2014 occurred a difference in number and types. The observations conducted in September 2013 showed that forage plant that has the largest cover area was Brachiaria brizantha as much as
$66.67 \%$. The observations which were carried out in September 2014 also showed the same results as the observation in September 2013 in which Brachiaria brizantha has the largest cover area by $75.15 \%$. Brachiaria brizantha is an ever-growing grass every year with height up to $120 \mathrm{~cm}$ and have a sturdy upright stem. This grass comes from tropical Africa and introduced to most tropical countries. Brachiaria brizantha can be grown in areas with an altitude up to $3000 \mathrm{~m}$ above sea level and grow in the spring to autumn. These plants are tolerant to a variety of soil types and acidic conditions. The cattle like this grass so much with the ratio of good leaf/stem (FAO, 2014). The benefit of Brachiaria brizantha grasses on permanent pasture is good to cover the grazing land (Prosea, 2014).

Based on the types of plants that grow in the grazing lands around Kali Kuning and Krasak River, it can be concluded that those grazing land are included in the mixed grazing land. It is called mixed grazing land because there also grows grasses and legumes. Mc Ilroy (1977), states that a mixed grazing land of grasses and legumes is more perfect and much preferable by the cattle than pure grass land. The function of legumes in the grazing land is to provide or give better food value, especially in the form of protein, phosphorus and calcium. Grasses provide more dry matter than legumes and more energy also for livestock (Reksohadiprodjo, 1994).

Table 2. Analysis Results of the of volcanic ash soil of Mount Merapi in 2011

\begin{tabular}{llcc}
\hline \hline \multicolumn{1}{c}{ Parameter } & Unit & Result \\
\hline $\mathrm{pH}$ & $\mathrm{H}_{2} \mathrm{O}$ & $\%$ & 5.9 \\
Texture & $\mathrm{KCl}$ & $\%$ & 5.3 \\
& Sand & $\%$ & 70 \\
& Ash & $\%$ & 26 \\
\multirow{3}{*}{ Organic matter } & $\mathrm{Clay}$ & $\%$ & 4 \\
& $\mathrm{C}$ & $\%$ & 0.21 \\
& $\mathrm{~N}$ & $\%$ & 0.01 \\
& $\mathrm{C} / \mathrm{N}$ & $\%$ & 15 \\
\hline
\end{tabular}

(Rostaman et al., 2011) 
Table 3. Analysis Results of the of volcanic ash soil of Mount Merapi in 2013

\begin{tabular}{lccc}
\hline & Parameter & Unit & Result \\
\hline $\mathrm{pH}$ & & & 5.9 \\
$*$ *Texture & Sand & $\%$ & 61.03 \\
& Ash & $\%$ & 20.43 \\
\multirow{2}{*}{ * Organic matter } & Clay & $\%$ & 18.54 \\
& $\mathrm{C}$ & $\%$ & 0.31 \\
& $\mathrm{~N}$ & $\%$ & 0.03 \\
\hline
\end{tabular}

Table 4. Percentage of cover area and the height of feed crops in area of kali Kuning and Krasak River during September 2013 and 2014

\begin{tabular}{clcc}
\hline \multicolumn{1}{c}{ Species Name } & Cover area $(\%)$ & Height $(\mathrm{cm})$ \\
\hline Year & Panicumrepens & 6.99 & 50 \\
& Cynodonsp & 13.94 & 45 \\
& Pennisetum purpureum & 29.15 & 205.2 \\
& Brachiaria brizantha & 66.67 & 43.5 \\
& Pennisetum purpuphoides & 22.78 & 138.7 \\
& Albazia sp. & 16.17 & 540 \\
& Caliandra calothyrsus & 33.94 & 112.5 \\
& Leucaena leucocephala & 5.25 & 85 \\
& Jackfruit trees & 8.47 & 800 \\
& Guava trees & 11.59 & 54 \\
\hline \multirow{2}{*}{2014} & Brachiaria brizantha & 75.15 & 93 \\
& Pennisetum purpuphoides & 3.58 & 80 \\
& Caliandra calothyrsus & 15.06 & 250 \\
& Mimosa pudica & 2.59 & 44 \\
& Acacia trees & 11.76 & 650 \\
& Guava trees & 2.11 & 35 \\
& Macroptilium arthropurpureum & 13.06 & 39 \\
& Pineapple bushes & 4.59 & 66 \\
\hline
\end{tabular}

The production of dry matter (DM) is the primary measurement of forages productivity. Forage dry matter in Kali Kuning and Krasak River can be seen in Table 5.

The highest dry matter in 2013 and 2014 was $165.57 \mathrm{gm}-2$ in Pennisetum purpuphoides and $190.37 \mathrm{gm}-2$ in Brachiaria brizantha, respectively. The production of king grass was twice as much as elephant grass, up to 40 tons of fresh grass/ha in once harvest time or equivalent with 200 to 250 tons of fresh grass hectare $^{-1}$ year $^{-1}$ (Susetyo, 2001). For Brachiaria brizantha grass, the harvest reaches 8-20 t hayear $^{-1}$, with stocking rates of 1.5 bulls ha $^{-1}$ in the dry season and 2.5 bulls during the rainy season. While the seeds can be obtained at the age of 6-8 months depending on the environmental and the seeds can reach 100$500 \mathrm{~kg} \mathrm{ha}^{-1}$ (Fanindi, 2012). Dry matter production is the result of the growth process during a certain period and in a certain unit area. Thus, the dry weight of the plant is influenced by the growth rate and the time of the composition of dry matter itself. Biomass above the soil surface is the weight of organic matter per unit on the land surface at any given time that are connected to one function, system productivity, stand elements and organic distribution (Onrizal, 2004). 
Dry matter production in the mixed planting system obtains higher outcome than dry matter production in monoculture planting system. This is due to in the mixed cropping system, the vegetation is vary so that the agricultural byproducts are higher than monoculture planting system. Various vegetation also produce various biomass productions so that the production of residual agricultural by-products (biomass) in the mixed land is higher than in the monoculture land (Lahjie, 2001).

\section{Chemical composition}

Potential nutritional value of ruminants forage is influenced by the forage chemical composition, digestibility, soil and its fertility, growth phase at the time of cutting or grazing, the surroundings, climate and fertilization (Arifuddin, 2014).

The chemical composition found in grasses and legumes grown around the slopes of Mount Merapi is including analysis on crude fiber (CF), crude protein (CP), crude fat (EE), dry matter (DM) and organic matter (OM). The average results of proximate analysis on grasses and legumes in September 2013 and September 2014 can be seen in the description in Table 6.

Proximate analysis results showed that the highest content of DM in September 2013 was in Pennisetum purpuphoides as much as $33.11 \%$ and the lowest was in Brachiaria brizantha as much as 28.22\%, whereas in September 2014 is the highest content of DM was in Brachiaria brizantha as much $37.69 \%$ and the lowest was $29.8 \%$ in Pennisetum purpuphoides. DM content of Brachiaria brizantha and Pennisetum purpuphoides increased in September 2014 but on Calliandra calothyrsus DM content decreased.

Dry matter is the benchmark to assess the palatability of foods needed to determine the quality of a feed. The ability of cattle to consume the food is the thing that should be considered as it is closely related to the level of that livestock production. This is due to variations of production capacity influenced by the food in the various types of livestock is determined by consumption (60\%), digestibility $(25 \%)$, and conversion of result of digestion products (15\%). The amount of food consumed by an animal is one of the important factors that directly affect the productivity of livestock (Parakkasi, 1985).

Based on Table 6, it shows that the organic matter content in Brachiaria brizantha and Calliandra calothyrsus has a significant difference, it shows that in September 2013, the highest OM content was on Caliandra calothyrsus as much as $92.92 \%$ and the lowest was $83.32 \%$ in Pennisetum purpuphoides, while in September 2014 the highest OM content was on Caliandra calothyrsus that is was $90.26 \%$ and the lowest was in Pennisetum purpuphoides which was $81.60 \%$.

The OM content is determined by the ash content of plants. The amount of ash content varies depending on the species of plants and the intensity of the sunlight. The sunlight which is captured by the leaf used for photosynthesis process to produce organic matter (Harjadi, 2002). Based on the data in Table 6, it can be seen that the content of the fiber crude in the three samples of forage in September 2013, and in September 2014 has no significant difference. This is probably due to the content of the soil around Krasak River in 2013 and 2014 there has been no difference that influenced the content of crude fiber in those three forages. The highest crude fiber contained in Brachiaria brizantha was 33.96\% and the lowest was $20.97 \%$ in Caliandra calothyrsus.

In September 2013 the highest CP content contained in Caliandra calothyrsus was $23.53 \%$ and the lowest was $6.8 \%$ in Brachiaria brizantha, while in September 2014 it shows the highest $\mathrm{CP}$ content contained on Caliandra calothyrsus 
Nafiatul Umami et al./Animal Production. 17(2):97-106, May 2015

Accredited by DGHE No. 81/DIKTI/Kep./2011. ISSN 1411-2027

Table 5. Production of forage dry matter in Kali Kuning and Krasak River in September 2013 and 2014

\begin{tabular}{lcc}
\hline \hline Species name & Production of DM in $2013\left(\mathrm{~g} \mathrm{~m}^{-2}\right)$ & Production of DM in $2014\left(\mathrm{~g} \mathrm{~m}^{-2}\right)$ \\
\hline Caliandra calothyrsus & 155.11 & 57.10 \\
Brachiaria brizantha & 137.03 & 190.37 \\
\hline Pennisetum purpuphoides & 165.57 & 73.02 \\
\hline
\end{tabular}

Table 6. Nutrient composition of several grasses in Merapi area

\begin{tabular}{|c|c|c|c|c|c|c|c|c|c|c|c|c|}
\hline \multirow[t]{3}{*}{ Spesies name } & \multicolumn{2}{|c|}{$\begin{array}{c}\text { DM content } \\
(\%)\end{array}$} & \multicolumn{2}{|c|}{$\begin{array}{l}\text { OM Content } \\
(\%)\end{array}$} & \multicolumn{2}{|c|}{$\begin{array}{l}\text { CF content } \\
(\%)\end{array}$} & \multicolumn{2}{|c|}{$\begin{array}{l}\text { CP content } \\
(\%)\end{array}$} & \multicolumn{2}{|c|}{$\begin{array}{c}\text { EE content } \\
(\%)\end{array}$} & \multicolumn{2}{|c|}{$\begin{array}{c}\text { Nitrogen Free Extract } \\
(\%)\end{array}$} \\
\hline & Sept & Sept & Sept & Sept & Sept & Sept & Sept & Sept & Sept & Sept & Sept & Sept \\
\hline & 2013 & 2014 & 2013 & 2014 & 2013 & 2014 & 2013 & 2014 & 2013 & 2014 & 2013 & 2014 \\
\hline \multirow[t]{2}{*}{ Brachiaria brizantha } & $28.220 \pm$ & $37.696 \pm$ & $88.293 \pm$ & $89.803 \pm$ & $33.456 \pm$ & $33.960 \pm$ & $6.8 \pm$ & $5.36 \pm$ & $3.730 \pm$ & $5.033 \pm$ & 44.5 & 45.45 \\
\hline & $0.121^{\mathrm{a}}$ & $0.723^{b}$ & $0.150^{\mathrm{a}}$ & $0.227^{b}$ & $1.750^{\mathrm{ns}}$ & $6.158^{\mathrm{ns}}$ & 1.04 & 1.10 & $0.660^{\mathrm{a}}$ & $0.332^{\mathrm{b}}$ & & \\
\hline \multirow[t]{2}{*}{ Pennisetum purpuphoides } & $33.110 \pm$ & $29.800 \pm$ & $83.323 \pm$ & $81.600 \pm$ & $31.556 \pm$ & $33.540 \pm$ & $13.2 \pm$ & $12.45 \pm$ & $2.393 \pm$ & $2.213 \pm$ & 36.18 & 33.41 \\
\hline & $0.166^{\mathrm{b}}$ & $0.556^{\mathrm{a}}$ & $0.135^{\mathrm{ns}}$ & $1.264^{\mathrm{ns}}$ & $2.247^{\mathrm{ns}}$ & $7.418^{\mathrm{ns}}$ & 2.0 & 2.11 & $0.267^{\mathrm{ns}}$ & $0.921^{\mathrm{ns}}$ & & \\
\hline \multirow[t]{2}{*}{ Calliandra calothyrsus } & $29.496 \pm$ & $34.730 \pm$ & $92.920 \pm$ & $90.260 \pm$ & $21.495 \pm$ & $20.975 \pm$ & $23.53 \pm$ & $24.09 \pm$ & $4.790 \pm$ & $6.843 \pm$ & 41.92 & 38.36 \\
\hline & $0.109^{a}$ & $0.017^{b}$ & $0.070^{\mathrm{b}}$ & $0.871^{a}$ & $0.190^{\mathrm{ns}}$ & $4.023^{\mathrm{ns}}$ & 2.3 & 2.32 & $1.949^{\text {ns }}$ & $0.909^{\mathrm{ns}}$ & & \\
\hline
\end{tabular}

${ }^{\mathrm{ab}}$ different subscription in the same rows shows significant different $(\mathrm{P}<0.01)$ 
was $24.09 \%$ and the lowest was $5.36 \%$ in the Brachiaria brizantha. The analysis showed that Caliandra calothyrsus contain the highest CP. This is in agreement with Mc Ilroy (1977) who states that the legume contains higher protein than the grass. Protein has an inverse function to CF (Susetyo, 1980). Tillman et al. (1998), states that the older the plant, the CP content decreases on the other hand the CF content increases due to hemicellulose lignification in the cell wall. In some studies showed that $\mathrm{N}$ fertilization will increase the crude protein content at all stages of plant growth and the increase of $\mathrm{CP}$ content is influenced by the increase of $\mathrm{N}$ given (Crowder and Chheda, 1982).

The availability of legumes in a region is very good protein source potency for ruminants. In addition to its high protein content, legumes are also a good source of protein escapes rumen fermentation so that the nitrogen contained in legumes are not only a source of nitrogen for the rumen microbes but also a source of amino acids that can be used directly by the ruminants (Arifuddin, 2014).

Based on the data in Table 6, it can be seen that the content of crude fat in Brachiaria brizantha has a significant difference in September 2013 and in September 2014, while the content of crude fat in Pennisetum purpuphoides and Calliandra calothyrsus have no significant difference. In September 2013 the highest EE content contained in Caliandra calothyrsus was $4.79 \%$ and the lowest at $2.39 \%$ in Pennisetum purpuphoides are shown in Table 6, whereas in September 2014 the highest EE content was in Caliandra calothyrsus as much as $6.84 \%$ and the lowest at $2.21 \%$ in Pennisetum purpuphoides.

Yunus (1997) states that the fat content of plants is largely determined by genetic factors or the plant varieties and fat is rarely stored in the leaves, plants or roots but is stored in the fruit or seed. Maynard and Loslie (1973) states that the fat content of the foods causes differences of energy in various foodstuffs as carbohydrates only produce $4.5 \mathrm{kcal} \mathrm{g}^{-1}$, protein $5.65 \mathrm{kcal} \mathrm{g}^{-1}$, while fat produces at least $9 \mathrm{kcal}$ $\mathrm{g}^{-1}$.

The largest extract matter without nitrogen content in September 2013, and in 2014 was in Brachiaria brizantha which was $44.5 \%$ and 45.45\%, while the smallest was in Pennisetum purpuphoides as much as $36.18 \%$ and $33.41 \%$. Tillman et al. (1998), states that the proximate analysis divides carbohydrates into 2 (two) components that are extract matter without nitrogen and crude fiber. Extract matter without nitrogen as carbohydrates which are soluble, including sugar, starch and hemisellulosa, while crude fiber as insoluble carbohydrates include cellulose, lignin, and some of pentosan-pentosan (Anggorodi, 1994). The production of kinggrass (Pennisetum purpuphoides) from several research showed that the dry matter yield depend on management planting method. Wijitphanet al. 2009 reported that the cutting height gave respons on dry matter production. They found that cutting at $0,5,10 \mathrm{nd} 15 \mathrm{~cm}$ height at 70 days old cutting interval were significant effects on average 2 years of dry matter yield wich obtain 65,707, 67,070, 69,697 and 71,403 $\mathrm{kg} / \mathrm{ha} /$ year. Kabi and Bareeba (2008) reported C. calothyrsus had the highest total herbage biomass yield of $45.9 \mathrm{t} /\left(\mathrm{ha} \mathrm{yr}^{-1}\right)$ at the 4 months cutting frequency, $M$. alba had yields of 18.6 and $18.4 \mathrm{t} /\left(\mathrm{ha} \mathrm{yr}^{-1}\right)$ at 2 and 6 months, respectively. The content of total digestible nutrients in September 2013 with the largest was Calliandra calothyrsus at $72.93 \%$ and the lowest was Brachiaria brizantha at 51.18\%, while the content of total digestible nutrients in September 2014, the largest was Calliandra calothyrsus at $66.50 \%$ and the lowest was at $51.51 \%$ in Pennisetum purpuphoides. Sutardi (1980), states that the total digestible nutrient used to measure the energy content of foodstuffs. Total digestible nutrient is a unit of energy that is based on all the animal feed 
nutrients which are digested, so that the total digestible nutrient value is almost equal to the digestible energy (DE).

\section{Conclusions}

Based on the research, it was gained that the widest cover area in September 2013 and in September 2014 was Brachiaria brizantha grass. Total production of DM in Pennisetum purpuphoidesin September 2013 was $165.57 \mathrm{~g}$ $\mathrm{m}^{-2}$, while in September 2014 the largest DM production was Brachiaria brizantha at $190.37 \mathrm{~g}$ $\mathrm{m}^{-2}$. The quality of forage around Krasak River increased in 2014 which was marked by the highest crude protein content on Caliandra calothyrsus at $24.09 \%$, but the crude protein content of Brachiaria brizantha and Pennisetum purpuphoides decreased to $6.47 \%$ and $12.45 \%$. This increase was due to the addition of organic matter contained in the soil and the weathering of minerals from year to year.

\section{References}

Abdullah L, Dewi AP, Hardjosoewignjo SH. 2012. Repositioning feed crops in the curriculum of faculty of animal science. National Workshop on Feed Plant. Division of Agrostologi, Department of Nutrition and Food Technology, Faculty of Animal Science, IPB, Bogor. 11-13 (In Indonesian).

Anggorodi R. 1994. General Animal Feed Science. PT. Gramedia, Jakarta.

AOAC. 2005. Official Methods of Analytical Chemist. $12^{\text {th }}$ ed. PO Box 540. Benjamin Franklin, Washington DC.

Arifuddin MS. 2014. Study of Nutritive Feed for Timor Deer (Cervus timorensis) in Lembah Palu, Central Sulawesi. Dissertation. Graduate program. Universitas Gadjah Mada, Yogyakarta.

Caratti JF. 2006. Line intercept: sampling method. USDA Forest Service Gen. Tech. Rep. RMRS-GTR164-CD.

Crowder LV, Chheda HR. 1982. Tropical Grassland Husbandry. $1^{\text {st }}$., Publ., Longman Inc., New York.

Cummings J, Smith D. 2000. The line-intercept method: A tool for introductory plant ecology laboratories. Pages 234-246, Tested in laboratory studies for teaching, Volume 22 (SJ Karcher, editor). Proceedings of the 22nd
Workshop/Conference of the Association for Biology Laboratory Education (ABLE), 489 pages.

Faninidi A, Prawiradiputra AB. 2012. Characterization and utilization of Brachiaria $S p$ grass. National Workshop of Animal Forage Feed. Livestock Research Institute, Bogor.

FAO. 2014. Brachiaria brizantha (A. Rich.) Stapf. Available at http://www.fao.org/ag/AGP/AGPC/doc/Gbase/d ata/pf000187.htm. Accession date: Dec $18^{\text {th }}$, 2014.

Harjadi SS. 2002. Introduction to Agronomy. $13^{\text {th }}$ Printing. PT. Gramedia Pustaka Utama, Jakarta.

Hartadi H, Reksohadiprodjo S, Tillman AD. 2005. Feed Composition Table for Indonesia. Fifth printing. Gadjah Mada University Press, Yogyakarta.

IAARD. 2010. Report on the rapid assessment (quick assessment) on the impact of the volcanoes eruption in agricultural sector. December 2010.

Kabi F, FB Bareeba. 2008. Herbage biomass production and nutritive value of mulberry (Morus alba) and Calliandra calothyrsus harvested at different cutting frequencies. Animal Feed Science and Technology. 140(1-2): 178-190

Kusnadi R. 2008. The types of Soil in Indonesia. Available at http://zahiosofie.wordpress.com. Accession date: Sep 29 ${ }^{\text {th }}, 2013$.

Lahije AM. 2001. Agroforestry Engineering. Grafika Publisher -UPVJ, Jakarta.

Maynard LA, Loosli JK. 1973. Animal Nutrition. $6^{\text {th }}$ edition. Tata McGraw Hill Publishing Company Ltd., New Delhi.

Mc Ilroy RJ. 1977. Introduction to Tropical Savannas Cultivation. Pradnya Paramita, Jakarta.

Onrizal. 2004. Estimates of Biomass and Cluster Carbon Model of Kerangas Forest in Sentarum Lake National Park, West Borneo. Thesis. Graduate School, IPB, Bogor.

Parakkasi A. 1985. Nutrition Science and Ruminant Feed. UI Press, Jakarta.

Prawiradiputra BR. 2003. Forage production systems in watershed dry land Jrantunseluna. Livestock Research Institute, Bogor.

Prawiradiputra BR. 2011. Feed plant to support the farms rehabilitation on the slopes of Mount Merapi. Wartazoa. 21(4). (In Indonesia).

Prosea. 2014. Brachiaria brizantha (A. Rich.) Stapf. Available at http://www.proseanet.org/prohati4/browser.ph p?docsid=345. Accession date: Dec $18^{\text {th }} 2014$.

Rostaman T, Anthony K, Linca A. 2011. The improvement of soil properties with a dose of volcanic ash on the Oxisols soil. Agricultural Research Agency in Soil Research Institute, Bogor. 
Reksohadiprodjo S. 1994. Forage Production of Tropics Feed. Third Edition. Agency Publisher Faculty of Economics, Yogyakarta.

Susetyo S. 1980. Animal Forage Feed. Director General of Animal Husbandry, Department of Animal Husbandry, Jakarta.

Susilo AN, R Iwan. 2010. Analysis of the risk level of Mount Merapi eruption on the settlements in Kemalang District, Klaten Regency. J. PWK Engineering. 3(1):34-49 (In Indonesia).

Sutardi T. 1980. Ruminology Overview. Department of Animal Feed and Science. Faculty of Animal Science, Bogor Agricultural Institute, Bogor.

Tillman AD, H Hartadi, S Reksohadiprodjo, S Prawirokusumo, S Lebdosoekojo. 1989. Foundation of Animal Feed Science. Faculty of
Animal Science, Universitas Gadjah Mada. Gadjah Mada University Press, Yogyakarta.

Tillman AD, H Hartadi, S Reksohadiprodjo, S Prawirokusumo, S Lebdosoekojo. 1998. Foundation of Animal Feed Science. Faculty of Animal Science, University of Gadjah Mada. Press Gadjah Mada University, Yogyakarta.

Wijitphan S, P Lorwilai, C Arkaseang. 2009. Effect of cutting heights on productivity of king nappier grass (Pennisetum purpureum cv.King grass) under irrigation. Pakistan Journal of Nutrition. 8(8):1244-1250.

Yunus M. 1997. Influence of Slaughtering Age and Grass Species on Production, Chemical Composition, and In Vitro and In Sacco Digestibility. Thesis. Graduate program. Gadjah Mada University, Yogyakarta. 